\title{
Sorting, Franchising and Real Estate Brokerage Firms
}

By: John D. Benjamin, Peter Chinloy, and Daniel T. Winkler

Benjamin, J. D., Chinloy, P., and D. T. Winkler. "Sorting, Franchising and Real Estate Brokerage Firms," Journal of Real Estate Finance and Economics, vol. 34, no. 2, 2007, pp. 189-206.

Made available courtesy of Springer Verlag: http://www.springerlink.com/content/102945/?p=c195eefaeb7c48e885f0dc34aecbbdc9\&pi=0

\begin{abstract}
:
Real estate markets remain localized and reflect differences by region. With a large number of brokerage firms and a smaller number of franchisors, a testable hypothesis is whether in equilibrium fees and royalties are equal to the additional return to the franchisee. If fees are set uniformly across the country, economic rents may be earned in specific local markets. Some franchisees may earn excess profits from the franchise arrangement. Empirical results for 1,143 United States residential brokerage firms in 2001 show standardized uniform franchising costs cover any added returns to franchises in the Midwest and South. Excess returns are present for franchisees in the Northeast. The probability of being a franchisee increases with size and scale. Keywords Franchise . Residential brokerage . Self-selection . Profitability . Regional variation . Fees . Royalties

\section{Introduction}

This paper models the decision by residential real estate brokerage firms to adopt a franchise. The industry is characterized by a large number of firms and relative freedom of entry and exit with respect to both doing business and choosing to be a franchise. At the same time, while any one franchisor sets fees that are uniform across the country, real estate markets retain local and regional characteristics. Across markets and regions, the franchisee will not accept the franchise if the fees and royalties exceed the additional return. But given the local nature of markets and barriers to entry, franchisees can receive added returns that cannot be captured by the franchisor without variable fees.
\end{abstract}

The model tests for excess returns from obtaining a franchise, given the fee structure. One testable hypothesis is that the franchisor will set fees to remove any excess returns if the market is fully competitive. Another is that franchisees in some markets obtain excess returns if the franchisor cannot charge differentiating fees. Statistical controls are introduced to separate other influences such as the size and scale of the firm. ${ }^{1}$

\footnotetext{
${ }^{1}$ In franchising, the franchisor or parent firm offers inputs such as common marketing, technology, and training in exchange for an upfront fee and royalty payments (typically a percentage of revenue). There are over one million Realtors ${ }^{\circledR}$ according to the National Association of Realtors ${ }^{\circledR}$ (see http://www.realtors.org) and approximately onethird are employed with franchised brokerage firms. The International Franchise Association (http://www.franchise.org) estimates that in 2000, franchisors and their franchisees had volume of $\$ 1$ trillion, more than $40 \%$ of all US retail sales. These sales originated from over 300,000 franchised businesses in 75 industries. Franchising is estimated to employ more than eight million people.
} 
The franchisor offers a set of inputs not directly available to participating firms. These inputs include common marketing, affiliation programs, branding, training and technology such as databases and software. Franchisees specialize in inputs in their local and regional markets, such as labor and facilities and clientele networks.

On the demand side, prospective franchisees evaluate net profits and returns from being in a franchise or remaining independent. On the supply side, the franchisor will accept the firm offering the highest expected profit or royalty revenue less its costs of provided inputs. The equilibrium sorts the type of firm by ability to generate profit and equates demand with supply. Initially all firms self-select whether or not they will enter into a franchise arrangement. Conditional on that decision, each firm experiences performance in earnings and net margin, separately for franchised and independent entities.

The residential brokerage industry provides a test platform, since franchised and independent firms coexist. With uniform fees across markets and with some markets having more barriers to entry than others, the prospect emerges for some franchisees to obtain excess returns. The marginal franchisee in some markets without barriers other than the franchise fees would earn no economic rent.

To test for sorting and these regional differences, residential brokerage firm data are used from a National Association of Realtors survey of 1,143 member firms in 2001, divided by region. ${ }^{2}$ The survey reports on net margins and net income, and therefore accounts for costs and expenses. In the sample, reported data for 313 firms that are franchisees and the remaining 830 that are nonfranchisees allows for sufficiently large sample sizes in each region.

Empirical results indicate that franchisees have higher revenue than independents. Net margins or returns after expenses, however, are lower for franchised firms than for independents. Net margins are higher at franchisees, but accounted for by franchise costs. These results confirm the underlying competitiveness of the residential brokerage industry.

The local nature of some real estate markets, however, creates regional differences. Franchise fees are sufficient to remove any excess returns in the South and the Midwest. That is not the case in the Northeast, where franchising realizes excess returns. The results suggest that uniform fees for franchises and barriers to entry create excess returns in some real estate markets. "Franchising and Real Estate Firms" describes franchising in the real estate brokerage industry. "The Franchise Model" presents the model. Data and empirical results are in "Data and Empirical Results." Concluding remarks are in "Implications and Conclusions."

\section{Franchising and Real Estate Firms}

Local markets are distinguished by preferences, reflected in design and regulationswith potential barriers to entry. Franchises are national, and focus on creating uniform operational procedures and standardized marketing platforms to take advantage of economies of scale and scope. Franchises with their national uniformity appear to be the antithesis of local individuality.

\footnotetext{
${ }^{2}$ Another survey was carried out by the National Association of Realtors in 2004, but was more restrictive in data availability about net income and margin.
} 
In business design and architectural style, franchises have been slowly prevailing over local operators. Regional differences in formats and design have been disappearing in the operational and architectural features of franchised real estate. ${ }^{3}$ These businesses strive for uniformity in performance and product quality, even though regional differences may exist. Jakle and Sculle (1999, 65-67) and Kincheloe $(2002,125)$ note that fast-food firms in design and architectural standards tend to prefer conformity to national rather than local tastes. Jakle and Sculle (1994, 17-18) indicate similar preferences for franchisees and independents vying with companyowned stores in the gas station business.

Franchised firms offer name recognition, marketing strength, affiliations with relocation services, economies of scale in technology, and consistency of product. That consistency and uniformity imposes a cost when not accommodating regional differences in tastes and preferences. Several regional tendencies evidence these differences. Franchisors may insist on larger facilities, creating incentives for noncooperative behavior by franchisees. Regional considerations may dictate the size of local franchises. With a franchise, networks and contacts on the ground that generate business may be ignored.

In residential real estate brokerage, the franchisor and franchisee have a common objective to increase the sale and listing of houses. Profits are created for both as they combine property, funds, and efforts to maximize joint sales. Existing research on franchising in real estate brokerage has concentrated on the uniform contract, even as there can be excess returns resulting from localized differences. Frew and Jud (1986) find that franchise affiliation has a positive effect on brokerage firm sales and house prices. Richins, Black, and Sirmans (1987) also support the idea that franchise affiliation increases revenues.

Franchised structures can contribute to more competitive brokerage fees. The United States Government Accountability Office (2005) has examined the residential brokerage industry. The context was proposed legislation allowing financial firms such as banks to enter residential brokerage and property management. The intention was to examine various existing competitive and industrial organization structures of the industry. The GAO $(2005,14)$ notes that the franchised brokerage firm ReMax has faced resistance in some markets, while fostering competition. The reason is that ReMax charges its licensed brokers and agents a fixed monthly desk fee. In exchange, the licensees collect all the generated commissions. This payment structure is conducive to lowering overall fixed commission rates.

Jud, Rogers, and Crellin (1994) in a national context estimate production technologies for franchised and independent real estate brokerage firms. Franchises sell more properties than independents, obtaining gross revenues that are $9 \%$ higher. ${ }^{4}$ Those revenues at the national level are sufficient to cover the royalties and franchise fees. The number of houses sold and revenue increases with both size and age.

\footnotetext{
${ }^{3}$ Kincheloe (2002) notes this observation for the fast-food industry and Jakle and Sculle (1994) in the gas station business. Franchised or centrally-operated businesses have imposed more uniform standards on members.

${ }^{4}$ The estimates of Jud et al. (1994) are after subtracting royalties, fees, and other charges associated with franchise affiliation. The role of brokerage firms in helping to set listing prices in a competitive marketplace has been examined by Knight, Sirmans, and Turnbull (1994) and Sirmans and Turnbull (1997).
} 
In Lewis and Anderson (1999), franchised firms are more efficient at allocating resources. Franchised firms have lower costs per unit than their independent competitors. The degree to which a firm is not obtaining the maximum amount of output from a given level of inputs is its X-inefficiency. Using NAR data in the 1990s, Lewis and Anderson find that franchised firms are more X-efficient. Franchises add market share during growing markets, and hold their share during slower markets. During a seller's market, franchises are more able to attract listings because of their marketing networks. During a slow buyer's market with many listings, independents benefit.

Regarding cost and technology, Anderson, Lewis, and Zumpano (2000) demonstrate that franchised firms are more efficient than independents, but franchises may not be more profitable. ${ }^{5}$ Lewis and Anderson (1999) show that franchised brokerage firms have lower costs than independents, but the average firm operates close to its efficient frontier. Franchised firms are more efficient in allocating resources, according to Anderson and Fok (1998), but independents have more scale and technical efficiency.

Table 1 compares the costs of acquisition and entry for three of the most widely- held real estate brokerage franchises, Century 21, ERA, and Coldwell Banker, with those of popular restaurant franchises. ${ }^{6}$ The Subway restaurant franchise is one with

Table 1 Comparative costs for franchises, inside and outside real estate

\begin{tabular}{lllllll}
\hline & Century 21 & ERA & Coldwell Banker & Subway & McDonald's & Dunkin Donuts \\
\hline $\begin{array}{l}\text { Total investment } \\
(\$ 000)\end{array}$ & $\$ 11-522$ & $\$ 43-206$ & $\$ 23-477$ & $\$ 86-213$ & $\$ 506-1,600$ & $\$ 255-1,100$ \\
$\begin{array}{l}\text { Franchise fee } \\
\begin{array}{l}(\$ 000) \\
\text { Royalty on sales }\end{array}\end{array}$ & To $\$ 25$ & To $\$ 20$ & $\$ 13-20$ & To $\$ 12.5$ & $\$ 45$ & $\$ 40-80$ \\
$\begin{array}{l}\text { Term of franchise } \\
\text { in years }\end{array}$ & 10 & $6 \%$ & $6 \%$ & $8 \%$ & $12.5 \%$ & $5.9 \%$ \\
$\begin{array}{l}\text { Personal net worth } \\
(\$ 000)\end{array}$ & $\$ 25$ & $\$ 25$ & $\$ 25$ & 20 & NA & NA \\
\hline
\end{tabular}

Source: Entrepreneur Magazine and various franchisor websites

relatively low acquisition and entry costs, but their entry costs are still higher than those for the three real estate brokerage franchises.

\section{The Franchise Model}

Franchisor-provided inputs involve economies of scale, such as common advertising to a mass or national market, purchasing, training, capital access, affinity programs, maintaining databases and technology. In exchange for the set of franchisor inputs, the franchisee pays a royalty as a

\footnotetext{
${ }^{5}$ Zumpano, Elder, and Anderson (2000) note that greater firm costs may have led to increased consolidation among brokerage firms to take advantage of economies of scale. Consolidation has encouraged even more franchising as franchising allows brokerage firms to substitute variable costs for fixed costs so as to reduce break-even output levels.

${ }^{6}$ An additional franchise is ReMax, which has costs and fees that are less homogeneous. ReMax operates with sales associates paying fixed costs for a desk fee and a chargeback on overhead and office expenses. In exchange, sales associates receive a larger percentage of the upside, essentially viewing the cost charged by ReMax as a call option on their earnings.
} 
percentage of gross revenue. Most franchising arrangements also require an up-front payment as an initial franchise fee. The incentives for boosting output motivate the franchise relationship (Martin, 1988), while competition for space and cannibalization within the geographic trade area drives down franchisee returns (Mazzeo, 2002). ${ }^{7}$

One test is whether additional returns from franchising are eliminated in an environment where fees are uniform across markets. Since the franchisor offers economies of scale through standardization, the franchise and royalty fees are uniform. Another test is whether the returns from franchising across markets are homogeneous.

The model is based on the stylized conditions in the real estate brokerage industry. The industry has a large number of firms, all of which are eligible to join a franchise. Those holding a franchise coexist with those not adopting. The number of franchisors by comparison with the potential number of franchisees is relatively small. Brokerage firms self-select into franchises based on observable variables. If there are fully competitive conditions among brokerage firms, the franchisor sets fees that eliminate any excess returns. However, if the franchisor is constrained to set uniform fees across the country in all markets, it is possible for some franchisees to obtain excess returns.

For a franchise model of the real estate brokerage firm, production occurs with directly purchased inputs $x$ such as the payments to sales associates, office space, and utilities. The technology includes shift variables a such as size and age, all permitted to vary across markets. The real estate firm has a choice between selecting a franchise or not. A franchisor offers inputs $\mathrm{z}$ including referral networks, national marketing, affiliate services, training and technology such as database services. For holding a franchise, the franchisee pays a fixed franchise fee and a variable royalty as a percentage of total revenue at rate $s .{ }^{8}$ Franchises are available at a price to all firms in the industry, but there is no prohibition against operating without one. If the brokerage firm decides to acquire a franchise, an indicator variable is $1=1$; otherwise the decision is $1=0$.

The brokerage firm's revenue without a franchise is $\mathrm{r}(\mathrm{x}, \mathrm{a})$ depending on the sales associate inputs and other purchased services $x$ and the fixed shift variables a. The cost of directly purchased sales associate commission splits, support labor, and office overhead is $c(x, a)$, increasing and convex. If the firm obtains a franchise, the revenue is $(1-s) r(x, z, a)$, where $s$ is the royalty payment. The franchisor provides marketing and other support $\mathrm{z}$ in exchange for the royalty. The franchisee's profit is revenue less cost or $(1-s) r(x, z, a)-c(x, a)$. The net margin

\footnotetext{
${ }^{7}$ Franchising contracts are methods of sharing and reallocating risk, as discussed in Gallini and Lutz (1992) and Lafontaine (1992). There have been other justifications for franchising. Prendergast (2002) views a franchise as a method for delegation when there is uncertainty in output. When there is more uncertainty, compensation is based on output. The franchise has been viewed as a mechanism similar to sharecropping, although there are enforcement issues should one party fail to comply (Lafontaine \& Raynaud, 2002).

${ }^{8}$ The franchisor may charge up-front fees and/or upfront fees. Sometimes franchise fees are a tradeoff for the royalty. In a model where there are both fees and royalties, the franchisee's benefit is added revenue. At maximum profit there is a negative tradeoff between the royalty and the franchise fee. Using the notation of Eq. 1, if the franchise fee is $\mathrm{k}$, differentiating totally at maximum profit $-r(x, z, a) \mathrm{d} s-\mathrm{d} k=0$, so $\frac{\mathrm{d} k}{\mathrm{~d} s}=-r(x, z, a)<0$.
} 
$y$ for a franchisee is the profit per dollar of net revenue, or $\frac{(1-s) r(x, z, a)-c(x, a)}{r(x, z, a)}$. The firm's net profit margin from becoming a member of a franchise network is

$$
y(x, z, a, I=1)=(1-s)-\frac{c(x, a)}{r(x, z, a)} .
$$

The franchisee hires its sales associates and makes other direct purchases $\mathrm{x}$. The franchisorprovided inputs $\mathrm{z}$ as well as its size and scale a help the franchisee to generate revenue and profits. When the decision is not to have a franchise, the firm's net profit margin is

$$
y(x, z, a, I=0)=1-\frac{c(x, a)}{r(x, 0, a)} .
$$

Here the residential brokerage firm sets the level of franchise-provided inputs $\mathrm{z}$ at zero, in exchange for retaining all the gross commission revenue. No royalty fee $s$ is paid.

The firm chooses to hold a franchise when the profit exceeds that from being independent, or

$$
\left\{\begin{array}{l}
y(x, z, a, I=1) \geq y(x, z, a, I=0) \\
s+\frac{c(x, a)}{r(x, z, a)} \leq \frac{c(x, a)}{r(x, 0, a)}
\end{array} .\right.
$$

The conditions 1, 2, and 3 obtain in different markets, but the franchisor sets common fee structures. So the up-front fixed fee $\mathrm{k}$ and the percentage royalty s are constant across markets. If the franchisor sets the royalty s too high such that the second inequality in Eq. 3 is reversed and firms are informed, none will adopt the franchise. On the other hand, if uniformity of agreement leads the franchisor to set the same royalty s around the country, Eq. 3 can hold as a strong inequality. The franchisor will effectively be under-pricing in some markets.

The ratio of expenses to revenue for a franchise including all fees must be less than the expense ratio for a non-franchised firm. Regardless of size and given the franchise terms, the firm selects to be a franchise when the net profit is positive. The condition 3 establishes the demand for a franchise. It may be optimal for the firm not to hold a franchise, in which case the weak inequality in Eq. 3 is reversed. A firm of a given size, location, or scale a will choose a franchise when it provides an enhancement, leading to

$$
\frac{\partial y(x, z, a, I=1)}{\partial a} \geq \frac{\partial y(x, z, a, I=0)}{\partial a} .
$$

The above condition applies to the demand side for franchises. There is a corresponding supply side from the franchisors. Franchisors, including firms across the quality spectrum of the market from Century 21 to Coldwell Banker to Sotheby's, provide national marketing, training, affinity relationships, technology, and branding. ${ }^{9}$ The franchisor offers inputs $\mathrm{z}$ in exchange for royalty $\mathrm{s}$. A given franchisor operates within the set of firms ranked by structure $a=1, \ldots$, A that provides the highest profit return. The franchisor supplies the same inputs to all firms, and its cost function is $\mathrm{c}(\mathrm{z})$. The profit condition is

\footnotetext{
${ }^{9}$ These franchisor inputs are developed to increase the market appeal for franchised brokerages which may reduce uncertainty for customers unfamiliar with the local market.
} 


$$
\pi_{F}=s \max _{x_{a}} r\left(x_{a}, z, a, I=1\right)-c(z) \quad a=1, \ldots, A .
$$

If franchisor-provided inputs $\mathrm{z}$ and its size and scale a help the franchisee to generate increased revenue, then the franchisor promotes that brokerage firm which offers the most benefits from franchising. ${ }^{10}$

The result is a two-stage self-selective process within each market or region. In the first stage, conditional on fixed attributes such as size and location a, firms select or reject the franchise contract. In the second stage, conditional on the first stage self-selection, firms achieve their success through the profit margin.

Let $\mathrm{I}^{*}$ be an index of intensity for choosing a franchise. This index is based on the condition $\mathrm{y}(\mathrm{x}(\mathrm{s}, \mathrm{z}, \mathrm{a}), \mathrm{z}, \mathrm{a}, \mathrm{I}=1)-\mathrm{y}(\mathrm{x}, 0, \mathrm{a}, \mathrm{I}=0)$. Letting $\mathrm{W}$ be a list of the variables that determine intensity, the franchise selection decision is

$$
\left\{\begin{array}{l}
I^{*}=W \alpha+v \\
I=1 \quad W \alpha+v>0 \\
I=0 \quad W \alpha+v \leq 0
\end{array}\right.
$$

The indicator variable is $\mathrm{I}=1$ if the firm chooses a franchise and zero otherwise. Here the variables $\mathrm{W}$ have parameter a. The disturbance is $\mathrm{v}$ with zero mean. Contingent on that choice, the firm has a performance variable y such as net margin, net income or gross revenue. Comparing firms with and not holding franchises

$$
\left\{\begin{array}{ll}
y_{1}=X \beta_{1}+\varepsilon_{1} & I=1 \\
y_{0}=X \beta_{0}+\varepsilon_{0} & I=0
\end{array} .\right.
$$

Here $X$ is a list of variables that affects performance. For franchised firms with $I=1$, the parameters are $\beta_{1}$ with disturbance $\varepsilon_{1}$. For the firms that choose not to have a franchise with $I=0$, the corresponding parameters and disturbance are $\left(\beta_{0}, \varepsilon_{0}\right)$. The three errors for the franchise determination and the two performances $\left(v, \varepsilon_{1}, \varepsilon_{0}\right)$ have variance-covariance matrix

$$
\sum=\left[\begin{array}{lll}
\sigma_{v v} & \sigma_{v 1} & \sigma_{v 0} \\
\sigma_{v 1} & \sigma_{11} & \sigma_{01} \\
\sigma_{v 0} & \sigma_{01} & \sigma_{00}
\end{array}\right]
$$

The expected values of the performance disturbances, contingent on the franchise choices are

$$
\left\{\begin{array}{l}
E\left(\varepsilon_{1} \mid v>-W \alpha\right)=\gamma_{1} \frac{f(-W \alpha)}{1-F(-W \alpha)} \equiv \gamma_{1} m_{1} \\
E\left(\varepsilon_{0} \mid v \leq-W \alpha\right)=\gamma-_{0} \frac{f(-W \alpha)}{F(-W \alpha)} \equiv \gamma_{0} m_{0}
\end{array}\right.
$$

This correction is obtained by estimating the performance equations, corrected for self-selection as: $^{11}$

\footnotetext{
${ }^{10}$ The selection process could include requirements related to capitalization, professional qualifications of personnel, etc. as well as market-driven criteria such as the number franchises offered in a particular geographic area.

${ }^{11}$ The self-selection procedure is as in Heckman, Lalonde, and Smith (1999).
} 


$$
\left\{\begin{array}{ll}
y_{1}=X \beta_{1}+\gamma_{1} m_{1}+\varepsilon_{1} & I=1 \\
y_{0}=X \beta_{0}+\gamma_{0} m_{0}+\varepsilon_{0} & I=0
\end{array} .\right.
$$

According to Eq. 9, the decision about whether or not to accept a franchise within a given market is associated with opposite-signed self-selection coefficients. With all other conditions equal and competitive entry and exit, franchised firms have higher revenue and income. The independents have a choice of whether to franchise. If they decline, they save the franchise fees, so the net margins are higher for independents if the market is competitive. The franchisor is constrained by setting its fees uniformly across markets. Those fees eliminate any excess returns at least in some markets, but the absence of variability can lead to the persistence of excess returns in others.

Adjusted for the conditional probability of holding a franchise, and after paying all required fees, the franchisee earns a positive excess return. This situation can occur if the residential brokerage business is imperfectly competitive, with barriers to entry and exit. These are all testable hypotheses for the self-selection coefficients as shown in Eq. 11, so

$$
\begin{cases}\text { franchise } & \gamma_{1}>0 \\ \text { independent } & \gamma_{0} \leq 0\end{cases}
$$

For the net margin

$$
\begin{cases}\text { franchise } & \gamma_{1}<0 \\ \text { independent } & \gamma_{0} \geq 0\end{cases}
$$

The empirical objective is to test for the benefits of a franchise. Those benefits vary not only by the size and structure of the firm, but also regionally. With some parts of a country growing faster than others, less-informed new residents looking for a house are attracted to a franchise by the assurance of uniform quality signaled by the franchised brand.

\section{Data and Empirical Results}

The data are from a survey conducted by the National Association of Realtors in March 2001 of residential brokerage firms in the United States on financial performance. The NAR survey contains information on revenue, income and net margin by firms organized by size, age, the use of technology, and whether or not there is a franchise. The net margin is gross revenue less expenses, so costs are implicitly included.

A key classification is by region. Firms with all characteristics are distinguished by the four Census regions of the Northeast, Midwest, South and West. Those four Census regions are typically used by the NAR for reporting transactions and sales. The Northeast includes New Hampshire, Vermont, Massachusetts, Maine, Connecticut, Rhode Island, New York, New Jersey and Pennsylvania. States in the Midwest in Region 2 are Indiana, Illinois, Michigan, Ohio, Wisconsin, Iowa, Kansas, Minnesota, Missouri, Nebraska and North and South Dakota.

The South includes Delaware, the District of Columbia, Florida, Georgia, Maryland, North Carolina, South Carolina, Virginia, West Virginia, Alabama, Kentucky, Mississippi, Tennessee, 
Arkansas, Louisiana, Oklahoma and Texas. The West in Region 4 includes Arizona, Colorado, Idaho, New Mexico, Montana, Utah, Nevada, Wyoming, Alaska, California, Hawaii, Oregon and Washington. Separate data sets on the variables and the resulting probit are constructed for each of the four regions, to test for homogeneity.

If more than $50 \%$ of a respondent's business is from commercial brokerage, the firm is removed in order to obtain a sample of firms that focus primarily on residential real estate. The result is 1,143 eligible firms. The empirical models for testing the franchise theory include probit and sample selection regressions. ${ }^{12}$ The probit and self-selection are for each region separately.

In the probit model, the dependent variable takes a value of one if the firm is a franchisee and zero if it is independent. The explanatory variables for the probit model are age of the firm as a measure of reputation (Age), having an affinity elationship (Aff), a relocation service (Reloc), the number of other services (Oser), medium-sized firm dummy variable (Mfirm), large-sized firm (Lfirm), and the

Table 2 NAR national residential real estate brokerage firm sample statistics

\begin{tabular}{|c|c|c|c|c|c|}
\hline Variable & Description & $\begin{array}{l}\text { Franchise }=0 \\
\text { Mean }\end{array}$ & $\begin{array}{l}\text { Franchise =0 } \\
\text { Standard } \\
\text { deviation }\end{array}$ & $\begin{array}{l}\text { Franchise }=1 \\
\text { Mean }\end{array}$ & $\begin{array}{l}\text { Franchise = } 1 \\
\text { Standard } \\
\text { deviation }\end{array}$ \\
\hline & Sample size $(N)$ & 830 & & 313 & \\
\hline Net margin & $\begin{array}{l}\text { Net margin, percentage } \\
\text { points }\end{array}$ & 20.02 & 19.80 & 14.70 & 16.37 \\
\hline Lnm & Natural log, net margin & 2.51 & 1.06 & 2.21 & 0.99 \\
\hline Revenue & Total firm revenue ( $\$$ million) & 11.39 & 83.66 & 22.08 & 138.76 \\
\hline Lrev & Natural log, total revenue & 13.79 & 2.24 & 14.41 & 2.02 \\
\hline Net income & $\begin{array}{l}\text { Total firm net income } \\
\text { (\$ million) }\end{array}$ & 1.39 & 9.88 & 2.46 & 15.87 \\
\hline Lni & Natural log, net income & 11.69 & 2.22 & 12.02 & 2.08 \\
\hline Reloc & $\begin{array}{l}=1 \text { if member of a relocation } \\
\text { network }\end{array}$ & 0.98 & 0.14 & 0.98 & 0.13 \\
\hline Aff & $\begin{array}{l}=1 \text { if member has an affinity } \\
\text { relationship }\end{array}$ & 0.72 & 0.45 & 0.69 & 0.46 \\
\hline Oser & Number of other services offered & 0.88 & 1.69 & 1.56 & 2.53 \\
\hline Age & $\begin{array}{l}\text { Length of time in business, } \\
\text { in years }\end{array}$ & 21.30 & 18.54 & 23.86 & 19.06 \\
\hline Oneoff & $=1$ if firm has only one office & 0.62 & 0.49 & 0.50 & 0.50 \\
\hline Mfirm & $\begin{array}{l}\text { Medium-sized firm, 11-200 } \\
\text { salespersons }\end{array}$ & 0.38 & 0.49 & 0.45 & 0.50 \\
\hline Lfirm & $\begin{array}{l}\text { Large firm, more than } 200 \\
\text { salespersons }\end{array}$ & 0.04 & 0.20 & 0.11 & 0.31 \\
\hline Numwebs & $\begin{array}{l}\text { Number of websites firm } \\
\text { is found on }\end{array}$ & 2.83 & 1.53 & 3.46 & 1.39 \\
\hline
\end{tabular}

number of third-party websites where listings are posted (Numwebs). ${ }^{13}$ The firms are grouped by size for the number of licensed brokers and agents employed. Small firms have 0-10, mediumsized firms 11-200 and large firms more than 200 licensees.

\footnotetext{
${ }^{12}$ Although it would be desirable to include a larger number of variables in both stages of the analysis, the NAR survey of brokerage firms reports a limited number of useful variables. In addition, many variables are substantially collinear.

${ }^{13}$ The other services offered by residential real estate brokerage firms include business brokerage, escrow service, home improvements, home inspections, home warranty, home insurance, other insurance, mortgage lending, moving services, securities brokerage, settlement services, termite inspection, title insurance and title search.
} 
In the second stage of the empirical analysis, a sample selection regression is estimated using the probabilities from the probit model. The dependent variable represents three profitability measures: the natural log of revenue, the natural log of net income, or net margin expressed as percentage points. The independent variables are Reloc, Age, Mfirm, Lfirm and a dummy variable for being a one office firm (Oneoff).

Table 2 presents the descriptive statistics of the 2001 sample; $26.51 \%$ or 313 of the firms are members of a franchise. The remaining 830 are not franchised. The mean revenue for the franchise firm sample is $\$ 22.08$ million or about 1.94 times the amount of the mean revenue for the independent sample. The mean net income for the franchise sample is $\$ 2.46$ million or 1.77 times the net income of the independent sample. The firm's profit is expressed as its net margin, which is the

Table 3 Regional and national estimates of franchise probit models

\begin{tabular}{|c|c|c|c|c|}
\hline \multirow[t]{2}{*}{ Variable } & Midwest & Northeast & South & National \\
\hline & $\begin{array}{l}\text { Coefficient } \\
\text { (z-statistic) }\end{array}$ & $\begin{array}{l}\text { Coefficient } \\
\text { (z-statistic) }\end{array}$ & $\begin{array}{l}\text { Coefficient } \\
\text { (z-statistic) }\end{array}$ & $\begin{array}{l}\text { Coefficient } \\
\text { (z-statistic) }\end{array}$ \\
\hline \multicolumn{5}{|l|}{ Probit: } \\
\hline Constant & $-0.4901(-0.714)$ & $-0.9928(-1.183)$ & $-1.3107(-2.225)^{\mathrm{a}}$ & $1.3300(-4.130)^{b}$ \\
\hline Age & $0.0042(1.092)$ & $0.0012(0.262)$ & $0.0006(0.115)$ & $0.0014(0.638)$ \\
\hline Aff & $0.0275(0.130)$ & $-0.3178(-1.390)$ & $0.4467(2.575)^{b}$ & $0.1056(1.119)$ \\
\hline Reloc & $-0.5919(-0.950)$ & $-0.2539(-0.325)$ & $-0.2691(-0.467)$ & $0.0390(0.126)$ \\
\hline Oser & $0.1082(2.017)^{a}$ & $0.0591(1.197)$ & $0.0532(1.345)$ & $0.0636(2.997)^{\mathrm{b}}$ \\
\hline Mfirm & $-0.2125(-1.128)$ & $-0.0264(-0.117)$ & $0.3293(2.049)^{a}$ & $0.1366(1.538)$ \\
\hline Lfirm & $-0.0887(-0.233)$ & $0.3089(0.555)$ & $0.6822(1.984)^{\mathrm{a}}$ & $0.4095(2.270)^{\mathrm{a}}$ \\
\hline Numwebs & $0.1300(2.050)^{a}$ & $0.2377(3.256)^{\mathrm{b}}$ & $0.1194(2.425)^{\mathrm{a}}$ & $0.1367(4.836)^{\mathrm{b}}$ \\
\hline \multicolumn{5}{|c|}{ Probit marginal effects: } \\
\hline Constant & $-0.1710(-0.717)$ & $-0.3215(-1.194)$ & $-0.4165(-2.250)^{\mathrm{a}}$ & $-0.4355(-4.183)^{b}$ \\
\hline Age & $0.0015(1.093)$ & $0.0004(0.262)$ & $0.0002(0.115)$ & $0.0005(0.638)$ \\
\hline Aff & $0.0096(0.130)$ & $-0.1029(-1.387)$ & $0.1419(2.589)^{b}$ & $0.0346(1.119)$ \\
\hline Reloc & $-0.2065(-0.950)$ & $-0.0822(-0.325)$ & $-0.0855(-0.467)$ & $0.0128(0.126)$ \\
\hline Oser & $0.0378(2.011)^{a}$ & $0.0191(1.193)$ & $0.0169(1.344)$ & $0.0208(2.994)^{b}$ \\
\hline Mfirm & $-0.0741(-1.129)$ & $-0.0085(-0.117)$ & $0.1046(2.057)^{\mathrm{a}}$ & $0.0447(1.540)$ \\
\hline Lfirm & $-0.0310(-0.233)$ & $0.1000(0.554)$ & $0.2168(1.987)^{a}$ & $0.1341(2.270)^{\mathrm{a}}$ \\
\hline Numwebs & $0.0454(2.054)^{a}$ & $0.0770(3.298)^{\mathrm{b}}$ & $0.0379(2.435)^{\mathrm{a}}$ & $0.0448(4.856)^{\mathrm{b}}$ \\
\hline Log likelihood & -155.63 & -102.63 & -202.50 & -639.88 \\
\hline Chi-squared & $16.62^{\mathrm{a}}$ & $24.19^{\mathrm{b}}$ & $24.63^{b}$ & $62.22^{\mathrm{b}}$ \\
\hline$N$ & 265 & 194 & 373 & 1,143 \\
\hline
\end{tabular}

The standard errors of the marginal effect coefficients for the West probit model could not be estimated a significant at the $5 \%$ level

${ }^{\mathrm{b}}$ significant at the $1 \%$ level

difference between revenues and expenses. The franchise net margin is lower, at $73 \%$ of the net margin for independent firms.

These initial sample means indicate higher revenue and net income, but lower net margin at franchised firms. However, self-selection and other factors such as firm size could also explain the differentials. A larger proportion of franchise firms are either medium or large firms. Therefore, a more in-depth analysis is needed to isolate the effects of the franchise fee and royalty. 
The first stage of the sample selection analysis is the estimation of the probit equation. ${ }^{14}$ Estimates are for the non-reference Regions 1-3 in the Northeast, Midwest and South and for the United States. If the coefficients in each region are identical, then there is homogeneity. The franchise fees are sufficient to capture all excess returns. The West had to be excluded because of the small sample size of franchised firms.

Table 3 shows the probit findings by region and nationally. Among the regional models, the South probit has the best fit. Unlike regression models, probit model coefficients cannot be directly interpreted unless they are converted by taking partial derivatives. These partial derivatives, or marginal effects, are reported in the bottom of the table.

Table 4 Tests for aggregation across regions

\begin{tabular}{lll}
\hline Aggregation tests across regions & & \\
\hline Empirical model & Franchise/independent & Likelihood ratio \\
\hline Probit & & $16.36^{\mathrm{a}}$ \\
Regression-revenue & Franchise & $65.36^{\mathrm{a}}$ \\
Regression-net income & Franchise & $63.08^{\mathrm{a}}$ \\
Regression-net margin & Franchise & $66.92^{\mathrm{a}}$ \\
Regression-revenue & Independent & $99.48^{\mathrm{a}}$ \\
Regression-net income & Independent & $90.02^{\mathrm{a}}$ \\
Regression-net margin & Independent & $84.64^{\mathrm{a}}$ \\
\hline
\end{tabular}

Likelihood ratio test with degrees of freedom $=\left(\right.$ Number of groups-1) ${ }^{*}$ Number of parameters. The pooled sample consists of firms from the Midwest, Northeast and South regions. The national region contains all four regions

a significant at the $1 \%$ level

The findings of the marginal effects in Table 3 indicate that affinity, number of other services provided, firm size, and number of third party website (Numwebs) listings are positively related to the probability of being a franchised firm. Only Numwebs is consistently and statistically significant in the national and regional probit models. When evaluated at the mean and within the sample range for Numwebs, the probability of being a franchise increases nationally by $4.48 \%$. The probability increases in a range from 3.79 to $7.70 \%$ depending on the region. Firms that offer other services are more likely to be franchises. Each service offered increases the probability by $2.08 \%$ in the national sample. Firm size increases the probability of being a franchise. Nationally, the probability increases by $13.41 \%$ for large firms only. In the South, the probability is $10.46 \%$ greater for medium size firms and $21.68 \%$ greater for large firms when evaluated at the means for the combined sample. ${ }^{15}$

Although separate probit models are shown by region, a likelihood ratio test reveals that the individual regional models are not statistically different from the model using the combined sample of firms from the Midwest, Northeast and South at the 5\% level of significance. The likelihood ratio test is calculated as $\mathrm{LR}=2 *\left(\mathrm{~L}_{\mathrm{U}}-\mathrm{L}_{\mathrm{R}}\right)$, where $\mathrm{L}_{\mathrm{U}}$ is the unrestricted logarithmic

\footnotetext{
${ }^{14}$ The probit model estimates are corrected for heteroscedasticity. All probit model and sample selection regressions were estimated using Limdep 8.0.

${ }^{15}$ When dummy variables are included in the probit model, a better approximation to determining the marginal effect is to compute the marginal effects at 0,1 for each dummy variable. This method, however, can lead to large number of estimated coefficients. Therefore, only the partial derivatives at the means are shown.
} 
likelihood. This is the sum of the logarithmic likelihood ratios for the three regions. The restricted logarithmic likelihood is $L_{R}$.

The test results for regional aggregation are in Table 4. The results indicate that the returns for the residential brokerage sample selection model differ across each region. These results indicate the possibility that unless royalty and franchise rates differ by market, not all excess returns are captured. There are underlying firm characteristics that are associated with a firm selecting a franchise. These include large size and the extent of scale and technology, reflected by the number of services

Table 5 Regional and national logarithmic total revenue estimates

\begin{tabular}{|c|c|c|c|c|}
\hline \multirow[t]{2}{*}{ Variable } & \multirow{2}{*}{$\begin{array}{l}\text { Midwest } \\
\text { Coefficient } \\
\text { (t-statistic) }\end{array}$} & \multirow{2}{*}{$\begin{array}{l}\text { Northeast } \\
\text { Coefficient } \\
\text { (t-statistic) }\end{array}$} & \multirow{2}{*}{$\begin{array}{l}\text { South } \\
\text { Coefficient } \\
\text { (t-statistic) }\end{array}$} & \multirow{2}{*}{$\begin{array}{l}\text { National } \\
\begin{array}{l}\text { Coefficient } \\
\text { (t-statistic) }\end{array}\end{array}$} \\
\hline & & & & \\
\hline \multicolumn{5}{|l|}{ Franchisees } \\
\hline Constant & $15.2786(8.389)^{b}$ & $16.4116(8.035)^{b}$ & $9.6857(4.271)^{b}$ & $13.5835(11.511)^{b}$ \\
\hline Reloc & $-0.3528(-0.221)$ & $-1.1663(-0.618)$ & $0.3467(0.189)$ & $-0.8593(-0.866)$ \\
\hline Age & $0.0057(0.572)$ & $0.0176(1.604)$ & $0.0445(4.480)^{\mathrm{b}}$ & $0.0260(5.037)^{\mathrm{b}}$ \\
\hline Oneoff & $-0.1025(-0.379)$ & $-0.8701(-1.659)$ & $-0.9199(-2.870)^{\mathrm{b}}$ & $0.0796(0.552)$ \\
\hline Mfirm & $1.6957(5.110)^{\mathrm{b}}$ & $1.0231(1.929)$ & $1.8138(3.677)^{\mathrm{b}}$ & $1.7717(8.483)^{b}$ \\
\hline Lfirm & $3.8917(3.503)^{b}$ & $1.7600(1.052)$ & $3.9528(3.225)^{\mathrm{b}}$ & $3.8253(6.762)^{b}$ \\
\hline Self-selection & $-2.0706(-2.279)^{\mathrm{a}}$ & $-1.6161(-2.316)^{\mathrm{a}}$ & $2.0675(2.163)^{a}$ & $-0.4224(-1.034)$ \\
\hline Adjusted $R^{2}$ & $0.56^{\mathrm{b}}$ & $0.43^{\mathrm{b}}$ & $0.41^{\mathrm{b}}$ & $0.43^{\mathrm{b}}$ \\
\hline \multicolumn{2}{|c|}{ Log likelihood -107.75} & -86.11 & -154.64 & -495.54 \\
\hline$N$ & 82 & 54 & 98 & 313 \\
\hline \multicolumn{5}{|l|}{ Independents } \\
\hline Constant & $8.8887(5.102)^{b}$ & $9.7077(6.900)^{b}$ & $11.5089(5.038)^{\mathrm{b}}$ & $9.5870(15.486)^{b}$ \\
\hline Reloc & $2.2034(1.759)$ & $1.1873(0.991)$ & $-0.5657(-0.262)$ & $1.1076(2.048)^{a}$ \\
\hline Age & $0.0296(2.544)^{\mathrm{a}}$ & $-0.0141(-1.304)$ & $0.0118(1.132)$ & $0.0132(2.162)^{a}$ \\
\hline Oneoff & $-1.2571(-2.624)^{\mathrm{b}}$ & $2.1431(3.606)^{\mathrm{b}}$ & $-0.1805(-0.582)$ & $-0.1401(-0.650)$ \\
\hline Mfirm & $0.7825(1.216)$ & $3.7851(4.710)^{\mathrm{b}}$ & $1.2377(2.184)^{a}$ & $1.4176(4.020)^{\mathrm{b}}$ \\
\hline Lfirm & $1.3441(0.576)$ & $8.2839(1.983)^{\mathrm{a}}$ & $2.9193(1.547)$ & $2.6579(2.246)^{a}$ \\
\hline Self-sel & $4.3031(2.916)^{b}$ & $-1.0628(-0.827)$ & $3.6655(2.323)^{\mathrm{a}}$ & $3.9419(4.245)^{b}$ \\
\hline Adjusted $R^{2}$ & $0.33^{\mathrm{b}}$ & $0.14^{\mathrm{b}}$ & $0.15^{\mathrm{b}}$ & $0.14^{\mathrm{b}}$ \\
\hline \multicolumn{2}{|c|}{ Log likelihood -324.75} & -303.01 & -528.91 & $-1,740.62$ \\
\hline$N$ & 183 & 140 & 275 & 830 \\
\hline
\end{tabular}

t-statistics are reported in parentheses below parameter estimates

a significant at the $5 \%$ level

${ }^{b}$ significant at the $1 \%$ level

and websites supported. Thus, at least in the first stage, a correction is required for specific factors affecting the franchise selection decision.

The second stage tests whether the fitted conditional probability of selection affects financial performance. In this stage, the estimation of the sample selection regressions uses weighted least squares to correct for sample heteroscedasticity. The weights used in this procedure are the sample weights from the survey, and they are designed to reflect the differential probability of firm and item non-response. ${ }^{16}$

${ }^{16}$ Historically, the National Association of Realtors surveys of real estate brokerages had suffered from a biased response where smaller brokerages responded at a rate significantly higher than that of larger brokerages. To correct for this in their 2001 survey, NAR stratified the brokerage industry's firms into four different groups. NAR then “over sampled" firms with 11-200 agents and those with more than 200 agents relative to firms with just one agent 
The findings of the sample selection regression for total revenue are shown in Table 5. Although both the national and regional regressions for the franchise and independent samples are statistically significant at the $1 \%$ level, the franchise

Table 6 Regional and national logarithmic net income estimates

\begin{tabular}{|c|c|c|c|c|}
\hline \multirow[t]{2}{*}{ Variable } & Midwest & Northeast & South & National \\
\hline & $\begin{array}{l}\text { Coefficient } \\
\text { (t-statistic) }\end{array}$ & $\begin{array}{l}\text { Coefficient } \\
\text { (t-statistic) }\end{array}$ & $\begin{array}{l}\text { Coefficient } \\
\text { (t-statistic) }\end{array}$ & $\begin{array}{l}\text { Coefficient } \\
\text { (t-statistic) }\end{array}$ \\
\hline \multicolumn{5}{|l|}{ Franchisees } \\
\hline Constant & $13.1233(5.771)^{b}$ & $12.5129(7.049)^{b}$ & $7.8816(3.073)^{b}$ & $10.7015(7.724)^{b}$ \\
\hline Reloc & $0.7356(0.370)$ & $-0.3353(-0.205)$ & $1.4443(0.696)$ & $0.3080(0.264)$ \\
\hline Age & $-0.0048(-0.375)$ & $0.0140(1.438)$ & $0.0386(3.424)^{b}$ & $0.0144(2.371)^{a}$ \\
\hline Oneoff & $-0.8765(-2.477)^{\mathrm{a}}$ & $-0.3122(-0.680)$ & $-1.0031(-2.720)^{\mathrm{b}}$ & $-0.0861(-0.508)$ \\
\hline Mfirm & $-0.1982(-0.458)$ & $0.2321(0.500)$ & $0.9354(1.681)$ & $0.7671(3.132)^{b}$ \\
\hline Lfirm & $2.9487(2.148)^{\mathrm{a}}$ & $1.5618(1.148)$ & $3.2267(2.429)^{\mathrm{a}}$ & $3.0767(4.658)^{b}$ \\
\hline Self-selection & $-2.0701(-1.842)$ & $-0.4668(-0.786)$ & $1.4764(1.375)$ & $-0.1039(-0.217)$ \\
\hline Adjusted $R^{2}$ & $0.16^{\mathrm{a}}$ & 0.08 & $0.24^{\mathrm{b}}$ & $0.14^{\mathrm{b}}$ \\
\hline \multicolumn{2}{|c|}{ Log likelihood - 135.61} & -80.47 & -168.53 & -545.91 \\
\hline$N$ & 82 & 54 & 98 & 313 \\
\hline \multicolumn{5}{|l|}{ Independents } \\
\hline Constant & $9.1721(8.191)^{b}$ & $8.7548(6.214)^{b}$ & $10.8079(6.037)^{b}$ & $7.0951(14.116)^{b}$ \\
\hline Reloc & $1.4215(1.680)$ & $0.0704(0.059)$ & $-0.7554(-0.447)$ & $3.0220(6.934)^{6}$ \\
\hline Age & $0.0274(3.830)^{\mathrm{b}}$ & $-0.0029(-0.265)$ & $0.0015(0.184)$ & $0.0085(1.658)$ \\
\hline Oneoff & $-0.4145(-1.472)$ & $2.5562(4.274)^{b}$ & $-0.1963(-0.807)$ & $0.0383(0.215)$ \\
\hline Mfirm & $-0.2945(-0.771)$ & $2.9194(3.606)^{b}$ & $0.6599(1.486)$ & $0.7122(2.360)^{a}$ \\
\hline Lfirm & $1.7105(1.163)$ & $6.8460(1.598)$ & $2.1668(1.466)$ & $2.4023(2.201)^{a}$ \\
\hline Self-selection & $0.8556(0.923)$ & $-0.5928(-0.457)$ & $2.4436(1.976)^{a}$ & $1.8251(2.295)^{\mathrm{a}}$ \\
\hline Adjusted $R^{2}$ & $0.13^{\mathrm{b}}$ & $0.11^{\mathrm{b}}$ & $0.06^{\mathrm{b}}$ & $0.10^{\mathrm{b}}$ \\
\hline \multicolumn{2}{|c|}{ Log likelihood -318.07} & -303.38 & -518.49 & $-1,763.87$ \\
\hline$N$ & 183 & 140 & 275 & 830 \\
\hline
\end{tabular}

t-statistics ane reported in parentheses below parameter estimates

a significant at the $5 \%$ level

b significant at the $1 \%$ level

regressions are more robust in all cases. The sample sizes for the franchise samples, however, are substantially smaller, thus magnifying the difficulty in achieving statistical significance for many coefficients.

In the national samples for franchises and independents, firm size appears to have the greatest and most widespread impact on franchise revenue. Although medium and large firms by head count have larger revenues, this relationship is more pronounced for franchise firms. Age contributes to total revenue. Each year of age increases revenues by $1.32 \%$ for the independent firms and $2.60 \%$ for franchises. For franchise firms in the South, the average increase per year is $1.85 \%$ higher than nationally. For the independent sample, the relocation service coefficient may be capturing some size effects. These services may be offered by larger independent firms. ${ }^{17}$

and those with two-ten agents. These "larger" firms received the survey twice to induce a greater response. A weight was developed to control for both the over sampling of firms with 11 or more agents and for the different response rate for each of the four stratified groups.

${ }^{17}$ Another anomaly is the coefficient for one office for independent firms in the Northeast region which would be expected to have a negative coefficient. However, regional samples have much smaller sample sizes, and moreover, given the multitude of estimated coefficients, some coefficients might show statistical significance due to random chance. 
The self-selection coefficient in the revenue regressions are shown in Table 5. For independent firms, the findings indicate positive coefficients for the self-selection that are statistically significant. But in Eq. 9, the self-selection conditional probability has a sign reversal from the estimated coefficient. Even after controlling

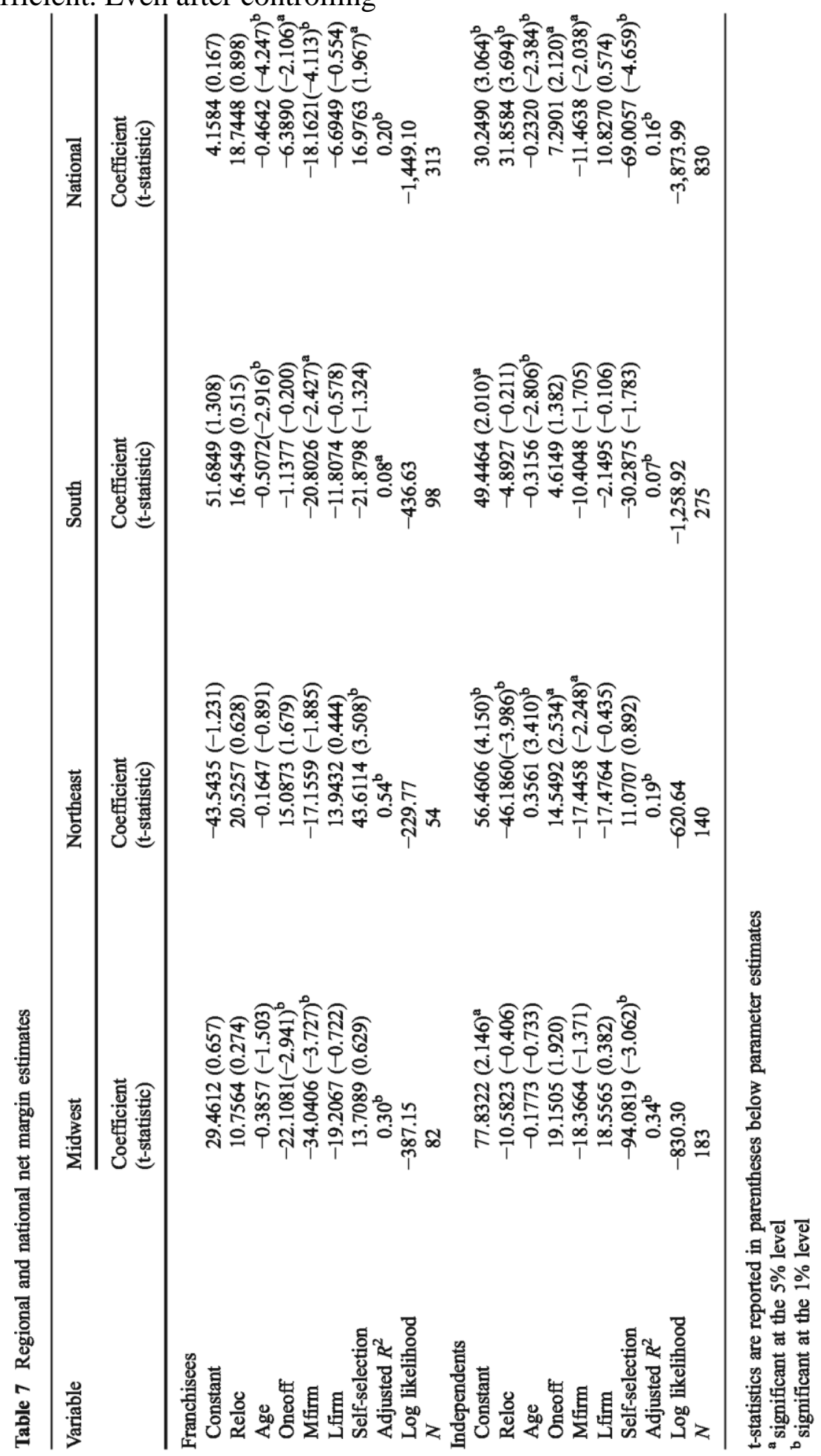


for size, scale, region, reputation and self-selection, independent firms have lower revenue than franchises. The findings of the franchise samples by region are mixed. The South coefficient is statistically significant and positive while the Midwest and Northeast sample selection coefficients have the opposite sign. The national franchise sample has a statistically insignificant self-selection coefficient. The self- selection indicates that independents have lower revenue in the US and all regions except the Northeast where the coefficient is insignificant, allowing for the sign reversal in Eq. 9.

Estimates for the dependent variable in Eq. 10 as y for net income are in Table 6 adjusted for self-selection. Similar to the findings of the revenue regressions, net income is most affected by head count as measured by medium and large firm size variables. Although the Oneoff coefficient is not statistically significant nationally, it is negative and statistically significant in the South for the franchise sample. For the independent sample, the Oneoff coefficient is positive and statistically significant in the Northeast. For franchises as a whole, each additional year of age increases net income by $1.44 \%$. In the South the increase is $3.86 \%$. These findings indicate that regional effects differ across the country.

The relocation coefficient is positive and highly significant for the national sample of independent firms, but not statistically significant for individual regions. ${ }^{18}$ The findings of the regional regressions indicate that franchise firms with one office in the South and Midwest have lower net income, which is statistically significant at the 1 and 5\% levels, respectively. Independent firms with only a single office and located in the Northeast have larger net income.

Independent firms have lower net income for both the United States and the South, based on the coefficient of the self-selection term, using the sign reversal of Eq. 9. In the Midwest and Northeast, the self-selection term is not significant. In none of the regions or in the US does the self-selection variable for franchise firms have a coefficient that is significantly different from zero. As a result, at least in the South and the country, there is lower net income for independents. The finding of lower net income for independent brokerage firms appears to be consistent with the contention by Lewis and Anderson (1999) that franchise firms have lower costs.

The final set of tests is to compare margins after all expenses, including for franchise fees. Those are reported in Table 6 . The net margin is gross revenues less all expenses including franchise and royalty fees, divided by gross revenues. This dependent variable is expressed in percentage or basis points.

Firm size appears to be less important in explaining the net margin than that for the revenue or net income models. Medium size firms have a lower profit margin than either small or large firms. From a regional perspective, medium-sized franchised firms have lower net margins in the Midwest and South. For independents, medium-sized firms have lower returns in the Northeast. One-office firms have a higher net margin for independents in the national sample, but a lower

\footnotetext{
${ }^{18}$ The large coefficient appears abnormally large, which could be explained by the relocation variable capturing other characteristics which leads to larger revenues. Note that $98 \%$ of both the franchise and independent samples are comprised of firms with relocation services. The remaining $2 \%$ of firms may be considerably smaller, and in areas with little migration from external markets.
} 
margin for franchises. Single-office firms may have difficulty generating sufficient revenues to pay the franchise fees and royalties. For the national samples, the negative coefficient for the age coefficient indicates that each additional year of age reduces the net margin by $0.46 \%$ for franchises and $0.23 \%$ for independents. ${ }^{19}$ This trend is not shared by independent firms in the Northeast, as the net margin increases by $0.36 \%$ for each additional year of age.

The results of Table 7 suggest that at least in the US and the Midwest, independents have higher net margins. The self-selection coefficient is negative, subject to the sign-change of Eq. 9. In the South, independents have higher net margins at a $10 \%$ confidence level, but not at the 5\% level. There is no significant difference in the Northeast.

In the upper panel of Table 7 are the results for the self-selection among franchisees. Selfselection increases the net margin in the United States, but with a magnitude lower than that for independents. Taking the differential, independents retain a higher net margin. For the Midwest and South, self-selection has no impact on franchisees. Since the Midwest has higher margins for independents, in this region this group can be said to have higher net performance. The result is similar in the South. Independents have higher net margins, though this conclusion is drawn only at $10 \%$ confidence levels.

The only difference is in the Northeast where franchised firms have higher net margins than independents. The self-selection coefficient is positive and significant for franchisees, raising net margin, while not significant for independents. These results may indicate potential market power for the franchisees, where a return is made over and above the franchisee fee and royalty payments. Otherwise, the Midwest, South and the United States indicate higher gross revenues but lower net margins for franchisees, revealing that fees and royalties lead to full capturing of returns by franchisors.

\section{Implications and Conclusions}

This 2001 NAR data set allows the direct testing of hypotheses about franchising in terms of firm profitability and size along with regional effects. First, the data allow for self-selection testing as to whether or not a residential brokerage firm adopts a franchise. Second, the sample allows for testing about whether the existing fee and royalty structure provides for effective sorting between franchise and non-franchise brokerage firms.

The findings indicate that franchisees usually are larger firms that offer a greater number of services. Independents generate less revenue than franchises, even when controlling for other extraneous influences. This result supports the contention that the franchisors are offering useful additional inputs to the revenue generating process including national marketing, training, affinity relationships, technology, and branding. Similarly, from a national perspective, independents appear to have lower net income relative to franchises, holding constant other influences.

\footnotetext{
${ }^{19}$ This might be explained by examining the national regressions for revenue and net income. While each has a positive relationship, the revenue coefficient is substantially larger than the net income coefficient. Taken together, it would be expected that the net income would decline with age.
} 
The performance and returns to franchised firms differ across the country. Franchise fees cover excess returns for the United States, Midwest and South. That is not the case in the Northeast, where there may be imperfectly competitive conditions that lead franchisees to obtain an excess return.

\section{Acknowledgements}

We are grateful to Paul Bishop, Anton Haidorfer, Ellen Roche, Marion Steele and two referees for their helpful comments and discussions. The data were provided by the National Association of Realtors.

\section{References}

Anderson, R. I., \& Fok, R. (1998). The efficiency of franchising in the residential real estate brokerage market. Journal of Consumer Marketing, 15, 386-398.

Anderson, R. I., Lewis, D., \& Zumpano, L. V. (2000). Residential real estate brokerage efficiency from a cost and profit perspective. Journal of Real Estate Finance and Economics, 20, 295-310.

Frew, J. R., \& Jud, G. D. (1986). The value of a real estate franchise. Journal of the American Real Estate and Urban Economics Association, 14, 374-383.

Gallini, N., \& Lutz, N. (1992). Dual distribution and royalty fees in franchising. Journal of Law, Economics, and Organization, 8, 471-501.

Heckman, J. J., Lalonde, R. J., \& Smith, J. A. (1999). The economics and econometrics of active labor market programs. In O. Ashenfelter \& D. Card (Eds.), Handbook of labor economics, Chapter 31, Volume 3A (pp. 1865-2097). New York: North-Holland.

Jakle, J. A., \& Sculle, K. A. (1994). The gas station in America. Baltimore: The Johns Hopkins University Press.

Jakle, J. A., \& Sculle, K. A. (1999). Fast food: Roadside restaurants in the automobile age. Baltimore: The Johns Hopkins University Press.

Jud, G. D., Rogers, R. C., \& Crellin, G. E. (1994). Franchising and real estate brokerage. Journal of Real Estate Finance and Economics, 8, 87-93.

Kincheloe, J. L. (2002). The sign of the burger: McDonald's and the culture of power. Philadelphia: Temple University Press.

Knight, J., Sirmans, C. F., \& Turnbull, G. (1994). List price signaling and buyer behavior in the housing market. Journal of the American Real Estate and Urban Economics Association, 9, 177192.

Lafontaine, F. (1992). Agency theory and franchising: Some empirical results. Rand Journal of Economics, 23, 263-283.

Lafontaine, F., \& Raynaud, E. (2002). The role of residual claims and self-enforcement in franchise contracting. National Bureau of Economic Research, NBER Working Papers: 8868.

Lewis, D., \& Anderson, R. I. (1999). Residential real estate brokerage efficiency and the implications of franchising: A Bayesian approach. Real Estate Economics, 27, 543-560.

Martin, R. (1988). Franchising and risk management. American Economic Review, 78, 954-968.

Mazzeo, M. J. (2002). Competitive outcomes in product-differentiated oligopoly. Review of Economics and Statistics, 84, 716-728.

Prendergast, C. (2002). The tenuous trade-off between risk and incentives. Journal of Political Economy, 110,1071-1102.

Richins, M. L., Black, W. C., \& Sirmans, C. F. (1987). Strategic orientation and marketing strategy: An analysis of residential real estate brokerage firms. Journal of Real Estate Research, 2, 41-54. 
Sirmans, C. F., \& Turnbull, G. (1997). Brokerage pricing under competition. Journal of Urban Economics, 41, 102-117.

United States Government Accountability Office (2005). Real estate brokerage: Factors that may affect price competition, Report to the Committee on Financial Services, United States House of Representatives, August.

Zumpano, L. V., Elder, H. W., \& Anderson, R.I. (2000). The residential real estate brokerage industry: An overview of past performance and future prospects. Journal of Real Estate Research, 6, 237-250. 